\title{
Brent prices and oil stock behaviors: evidence from Nigerian listed oil stocks

\author{
Amarachi Uzo-Peters ${ }^{1}$, Temitope Laniran ${ }^{1,2^{*}}$ and Adeola Adenikinju ${ }^{1}$
}

\author{
* Correspondence: \\ lanirantemitope@gmail.com \\ ${ }^{1}$ Centre for Petroleum, Energy \\ Economics and Law, University of \\ Ibadan, Ibadan, Nigeria \\ ${ }^{2}$ Bradford Centre for International \\ Development, University of \\ Bradford, Bradford, UK
}

\begin{abstract}
Background: Given the shale oil glut that culminated in the most recent and continuing oil price drop from June 2014 and the global financial crisis of 2008 that triggered a cyclical downturn in oil prices and stock market activity, this study investigates the impact of Brent oil price shocks on oil related stocks in Nigeria.
\end{abstract}

Methods: This study uses a vector autoregressive (VAR) model with the impulse response function and the forecast variance decomposition error.

Findings: The empirical evidence reveals that oil price shocks have a negative impact on Nigerian oil and gas company stocks. In theory, this situation should apply to oil importing countries and is therefore uncharacteristic of an oil exporting country like Nigeria.

Conclusions: The findings suggest that oil companies operating in Nigeria should diversify their investments to protect their business from single-sector market forces, and can also embrace the advantages of outsourcing some of their operations to specialist providers to increase flexibility and reduce operating costs. Finally, for vertically integrated oil and gas companies, oil price hedging and energy risk management will be beneficial because it will mean that these companies will take a position in the crude oil futures market. This will allow for better cash flow management and flexibility.

Originality/value: This study extends the existing literature in two distinct ways. First, it provides, to the best of our knowledge, the first examination of the impact of oil price shocks on stock market activities with a focus on the market returns of oil and gas companies listed in the Nigerian Stock Exchange. Second, this study uses daily data because high frequency data contain more information than lower frequency data does, and lower frequency data average out too much important information.

Keywords: Oil price shock, Stock markets, VAR, Impulse response, Nigeria

\section{Introduction}

Sharp fluctuations in oil prices are generally seen as a major contributor to business cycle asymmetries. Historical highs in the world oil market created concerns about possible slowdowns in the economic performance of the most developed countries. Most recently, declines in the world oil price caused oil exporting countries such as Russia and Nigeria to cut their national budgets. Thus, not surprisingly, a considerable body of economic research studies the channels through

(c) The Author(s). 2018 Open Access This article is distributed under the terms of the Creative Commons Attribution 4.0 International License (http://creativecommons.org/licenses/by/4.0/), which permits unrestricted use, distribution, and reproduction in any medium, provided you give appropriate credit to the original author(s) and the source, provide a link to the Creative Commons license, and indicate if changes were made. 
which oil price shocks influence economic variables for oil-importing, oilexporting, developed, and emerging economies.

While extensive studies of the oil price macro-economy relationship exist, a strand of the literature concentrates on the impact of oil price shocks on the financial market, particularly the stock market. Although these studies use different methods and alternative data sources, the relationship between oil price shocks and stock market performance remains unresolved. For example, while Jones and Kaul (1996) and Sadorsky (1999) report a significant negative connection between oil price shocks and stock market returns, Huang et al. (1996) and Sadorsky (2001) establish a positive relationship.

Besides the conflicting findings and conclusions, earlier studies on the relationship between oil prices and stock market returns mainly concentrated on advanced economies. The internationalization of global capital markets and the increasingly important role of emerging markets globally prompted scholars to investigate the mechanism through which the international oil price affect stock markets in emerging economies. Basher and Sadorsky (2006) provide one of the earliest comprehensive studies on this subject and find a strong link between oil price volatility and stock returns within emerging markets. Babatunde et al. (2013) concentrate on a leading oil producer, Nigeria, and reveal that depending on the nature of oil price shocks, Nigerian stock market returns exhibit a positive response, but after some time, the response becomes negative.

This study follows this direction of research and tests the relationship between international oil prices and stock market returns in Nigeria, with a particular focus on oil and gas related companies/stocks. The major objective of this study is therefore to examine the relationship between crude oil price and oil and gas related stocks in the Nigerian Stock Exchange (NSE). This study extends the existing literature in two distinct ways. First, the study provides, to the best of our knowledge, the first examination of the impact of oil price shocks on stock market activities, concentrating on the market returns of oil and gas companies listed in the NSE. Previous studies such as Babatunde et al. (2012), Asaolu and Ilo (2012), and Effiong (2014) focus on the impact of oil price volatility on the NSE without concentrating on the type of stocks, as this study does. Second, this empirical study uses daily data with the assumption of reducing averaging biases, since it captures more data points. Pioneering studies by Babatunde et al. (2012) and Adaramola (2012) use quarterly data, while more recent studies such as by Effiong (2014) use monthly data for their study periods.

Although the NSE has fourteen (14) oil and gas companies listed, this study uses the daily closing prices for eight oil and gas companies listed in the NSE continuously between January 4, 2007, and December 31, 2014, except Beco Petroleum Product Plc., which was listed from July 2009. For crude oil prices, we refer to the European Brent Crude oil fixed order book (FOB) price, in dollars per barrel.

The rest of the paper proceeds as follows. Theoretical framework section discusses the arbitrage pricing theory (APT) framework. Estimation technique and model specification section presents the estimation technique and model specification. Data and empirical analysis section reports the empirical analysis and results. Finally, Conclusion and recommendation section provides the conclusions and recommendations. 


\section{Theoretical framework}

The macroeconomic approach to asset valuation is the most adaptable to this study because it values stocks using factor analysis, which incorporates macroeconomic variables (oil price inclusive) into its technique. The arbitrage pricing theory (APT) is the underlying theory under this approach. Ross (1976) developed APT, which underpins this approach. The theory holds that the expected return of a financial asset can be modeled as a linear function of various macro-economic factors (e.g., inflation, gross domestic product, and oil prices). APT is an alternative model that potentially overcomes the capital asset pricing model's problems while retaining its underlying message. The core idea of APT is that only a small number of systematic influences affect the long term average returns of securities.

The first element of Ross's APT is a factor model. Multi-factor models allow an asset to have not just one, but many measures of systematic risk. Each measure captures the sensitivity of the asset to the corresponding pervasive factor. If the factor model holds exactly and assets do not have specific risk, then the law of one price implies that the expected return of any asset is just a linear function of the other assets' expected return. If this were not the case, arbitrageurs would be able to create a long-short trading strategy that would have no initial cost and give positive profits.

The central idea behind APT is that we can price some assets relative to other assets when such assets have no specific risk. Therefore, when there are no specific risks, all asset prices move together and are therefore just leveraged 'copies' of one other. The result becomes more difficult when assets have specific risk. In this case, it may be possible to form portfolios by diversifying away specific risks.

Given these assumptions and the intuition of APT, we can break actual return, R, on an asset (be it a stock, bond, or portfolio) into three constituent parts, which we can express mathematically, as follows:

$$
\mathrm{R}=\mathrm{E}+b f+e
$$

where $\mathrm{E}$ is the expected return on the asset, $\mathrm{b}$ is the asset's sensitivity to a change in the systematic factor, $\mathrm{f}$ is the actual return on the systematic factor, and e is the return on the unsystematic, idiosyncratic factors.

Equation (1) states that the actual return of an asset equals the expected return plus factor sensitivity times factor movement plus residual risk. However, in reality, assets tend to have more than one systematic factor because there are several important factors. Without representing each one, understanding the capital market becomes difficult. Therefore, we must expand the basic equation in (1) to incorporate multiple systematic factors. Prior empirical work suggests that a three or four factor model adequately captures the influence of systematic factors on stock market returns (Roll and Ross 1984). We can thus expand Eq. (1) to:

$$
R=E+(b 1)(f 1)+(b 2)(f 2)+(b 3)(f 3)+(b 4)(f 4)+e
$$

Each of the four middle terms in Eq. (2) is the product of the returns on a particular economic factor and the given asset's sensitivity to that factor. These factors are the underlying economic forces with a primary influence on the stock market. Roll and Ross (1984) suggest that the most important factors are (1) unanticipated inflation, (2) changes in the expected level of industrial production, (3) unanticipated shifts in risk 
premiums, and (4) unanticipated movements in the shape of the term structure of interest rates.

The advantage of this factor analytic technique is that the factors determined from the data explain a large proportion of the risks in that particular dataset over the period under consideration. The drawback is that factors usually have no economic interpretation. As Roll and Ross argue, an effort should be directed at identifying a more meaningful set of sufficient statistics for the underlying factors.

An alternative to factor analytic techniques is to use observed macroeconomic variables as the risk factors. Chen et al. (1986) were among the first to use observed factors, and argue that at the most basic level, some fundamental valuation model determines the prices of assets. Therefore, the choice of factors should include any systematic factors that affect future dividends, which is how traders and investors form expectations, and the rate at which investors discount future cash flows.

Although we do not employ factor analysis in our study, instead we use macroeconomic variables in line with (Chen et al. 1986; Hamao 1988). The basic economic assumption dictates our choice of variables, bearing in mind the concept of asset pricing that applies regardless of the market type and location. By taking this approach, we can discuss the different magnitudes of the influence of the oil price on individual stocks in the NSE.

\section{Estimation technique and model specification}

We adopt vector auto regression (VAR) analysis in order to present a multivariate framework that expresses each variable as a linear function of its own lagged value and the lagged values of all other variables in the system. The advantage of this approach is its ability to capture the dynamic relationships among the variables of interest. We used the Eviews 7 software package to run the test analysis.

Unlike the simultaneous, or structural equation, models, which treat some variables as endogenous and some as exogenous or predetermined (exogenous plus lagged endogenous), VAR models treat all variables as endogenous. Therefore, there is no a priori distinction between endogenous and exogenous variables. We can express our model as:

$$
Y_{t}=c+\Pi_{1} Y_{t-1}+\Pi_{2} Y_{t-2}+\ldots+\Pi_{p} Y_{t-p}+\varepsilon_{t} ; \quad t+1, \ldots, T
$$

Where $Y_{t}=\left(y_{1 t}, y_{2 t}, y_{3 t}, \ldots, y_{n t}\right)^{\prime} ; \mathrm{n}$ denotes the number of endogenous variables. $\mathrm{p}$ is the lag length and $\Pi_{t}$ is a $(n \times n)$ matrix of coefficients and $\mathrm{t}$ is the time period. $\varepsilon_{t}=\left(\varepsilon_{1 t}, \ldots, \varepsilon_{n t}\right)^{\prime}$ represents shocks in the VAR model.

To find an appropriate VAR model, it is essential to determine an optimum lag length for the VAR model, for which we can use information criteria (Parivash and Tarkamani 2008). Since the estimated coefficients from VAR models often appear to lack statistical significance due to the inaccurate estimates of standard errors, researchers often use impulse response functions (IRFs) and forecasting variance decomposition to explain the dynamic effects of the shocks on the endogenous variables. An IRF traces the effect of a one-time shock to one of the innovations on the current and future values of the endogenous variables. While IRFs trace the effects of a shock to one endogenous variable on the other variables in the VAR, variance decomposition separates the variation in an endogenous variable into the component shocks to the VAR. In this study, we use two variables: stock price (sp) and oil price $(\mathrm{O})$. We obtain stock price returns $(\mathrm{spr})$ from the stock price using the 
transformation $s p r=\ln (s p t)-\ln (s p t-1)$, where $s p t$ denotes the stock price at time $\mathrm{t}$ and $s p t$ - 1 denotes the stock price lagged by one period. We transform oil prices into shock variables, i.e., oil price shocks (OS), using the scaled oil price method (SOP) developed by Lee et al. (1995), which Jiménez-Rodríguez and Sánchez (2005) and Aziz and Dahalan (2015) later use.

$$
\left.\begin{array}{l}
S_{S P I}=\max \left\{0,\left(\hat{\mu}_{t} / \sqrt{\sigma_{t}}\right)\right\} \\
S_{t} D_{t}=\min \left\{0,\left(\hat{\mu}_{t} / \sqrt{\sigma_{t}}\right)\right\}
\end{array}\right\}
$$

Where SOPI is scaled oil price increase, while SOPD denotes scaled oil price decreases. $\hat{\mu} t$ is the residual mean and $\sqrt{ } \sigma t$ is the square root of the volatility, which we derive using equation system (5) below. For this specification, the GARCH (p, q) model proposed by Bollerslev (1986) has become popular, particularly due to its explanatory power for dependence in volatility, which we estimate as follows:

$$
\left.\begin{array}{l}
O_{t}=\mu+\sum_{j=1}^{q} \eta_{j} O_{t-j}+\mu_{i, t} \\
\sigma_{t}^{2}=\alpha_{0}+\sum_{k=1}^{q} \alpha_{k} \mu_{t-k}^{2}+\sum_{j=1}^{p} \beta_{j} \sigma_{t-j}^{2}
\end{array}\right\}
$$

where $\mu t$ is white noise with $\left(\mu_{t} / \mu_{t-1}\right) \sim N\left(0, \sigma_{t}^{2}\right)$.

In addition, a bivariate ( ) system with stock price return and oil price shock was proposed to analyze the impulse and variance decomposition structure. We write the model in the reduced form of a structural VAR representation as follows:

$$
\left.\begin{array}{l}
\operatorname{spr}_{t}=\beta_{10}+\sum_{i=1}^{p} \beta_{1 i} \text { spr }_{t-i}+\sum_{i=1}^{p} \alpha_{1 i} O S_{t-i}+\mu_{1 t} \\
O S_{t}=\beta_{20}+\sum_{i=1}^{p} \beta_{2 i} O S_{t-i}+\sum_{i=1}^{p} \alpha_{2 i} \text { spr }_{t-i}+\mu_{2 t}
\end{array}\right\}
$$

where sprt is the log-return of the daily company stock price and $O S_{t}$ is the corresponding oil price shock variable, $S O P I_{t}$.

\section{Data and empirical analysis}

\section{Data sources}

This study uses a secondary dataset consisting of daily stock price and oil price from January 2007 to December 2014. We obtained the relevant stock prices from the NSE daily official list and the oil price from the Energy Information Administration (EIA). To ensure that both prices are in the same currency, we multiplied the oil price (\$) for each day by the exchange rate between the dollar and the naira for that day. The data contains approximately 1989 daily observations per company.

\section{Descriptive statistics}

Appendix 1 presents the names of the oil companies of interest and their dates of listing on the NSE. We conducted a preliminary analysis to determine the normality of the data, measures of central tendency, and measures of dispersion. In Table 1 below, we present the descriptive statistics of the stock returns of the oil and gas companies. The average daily stock returns for all companies are negative, except for FORTE OIL and OANDO PLC. FORTE OIL has the highest average daily return (0.000814), while BECO PLC has the lowest average daily return $(-0.00161)$. The size of the standard deviation indicates the risk of the 
Table 1 Descriptive statistics of oil and gas company stock returns

\begin{tabular}{lllllllll}
\hline & Beco Plc & Conoil Plc & Eterna Plc & Forte Plc & Mobil Plc & MRS Plc & Oando Plc & Total Plc \\
\hline Mean & -0.00161 & -0.00028 & $-5.32 \mathrm{E}-08$ & 0.000814 & -0.00006 & -0.00057 & 0.000479 & -0.00013 \\
Median & 0.0000 & 0.0000 & 0.0000 & 0.0000 & 0.0000 & 0.0000 & 0.0000 & 0.0000 \\
Maximum & 0.2877 & 0.5839 & 1.1787 & 0.9051 & 0.5274 & 0.6493 & 3.1822 & 0.3738 \\
Minimum & -0.6931 & -0.5839 & -1.0986 & -0.9051 & -0.4827 & -0.6493 & -2.9957 & -0.3738 \\
Std. Dev. & 0.034433 & 0.039534 & 0.152728 & 0.073422 & 0.03464 & 0.042814 & 0.896986 & 0.028415 \\
Skewness & -14.2237 & 0.114235 & 0.233937 & 0.292479 & -0.49603 & 0.145317 & 0.043657 & 0.557994 \\
Kurtosis & 280.9551 & 60.66494 & 31.81856 & 78.39369 & 77.61097 & 74.80754 & 4.946315 & 58.66135 \\
Jarque-Bera & $2,221,693$ & $266,439.5$ & $65,073.7$ & $453,579.8$ & $444,030.6$ & $390,168.1$ & 306.3501 & $248,212.8$ \\
Probability & 0.000 & 0.000 & 0.000 & 0.000 & 0.000 & 0.000 & 0.000 & 0.000 \\
\hline
\end{tabular}

company's stock returns. OANDO PLC returns have the highest standard deviation, while TOTAL PLC returns have the lowest standard deviation. All companies' daily returns exhibit excessive kurtosis, a fairly common occurrence in high frequency financial time series data, and suggest that this excessive kurtosis may be due to heteroscedasticity in the data, which the GARCH models may capture. Excessive kurtosis would also explain the reasoning for high Jarque-Bera statistics, which reject the null hypothesis of normality for all return series.

\section{Empirical results}

As equation system (6) represents, we conducted a VAR analysis to estimate the SOPIt type shock variable and we model the volatility of crude oil returns with an AR(1)$\operatorname{GARCH}(1,1)$ specification. Table 2 presents the test results. All parameter estimates of the AR (1)-GARCH $(1,1)$ model are highly statistically significant. We use the sum of $\beta 1$ to measure the persistence in volatility and $\alpha 1$ in the GARCH model is closer to unity for each period.

All five lag length criteria tested indicated 8 lags as the optimal model, so we consider it as the lag for our model estimation for all companies. We present only the maximum lag length (see Appendix 2).

Table 2 GARCH variance estimation results

\begin{tabular}{lllllll}
\hline & \multicolumn{3}{l}{ Mean equation } & & & \multicolumn{3}{l}{ Variance equation } \\
\cline { 2 - 3 } & $\mu$ & $\eta_{1}$ & & $a_{0}$ & $a_{1}$ & $\beta_{1}$ \\
\hline Beco Plc & $0.398600^{\mathrm{a}}$ & $0.995949^{\mathrm{b}}$ & & $0.035005^{\mathrm{b}}$ & $0.927270^{\mathrm{b}}$ & $0.061627^{\mathrm{b}}$ \\
Conoil Plc & $0.419389^{\mathrm{a}}$ & $0.995747^{\mathrm{b}}$ & & $0.033552^{\mathrm{b}}$ & $0.927481^{\mathrm{b}}$ & $0.062076^{\mathrm{b}}$ \\
Eternal Plc & $0.371797^{\mathrm{a}}$ & $0.996200^{\mathrm{b}}$ & & $0.032791^{\mathrm{b}}$ & $0.931361^{\mathrm{b}}$ & $0.058615^{\mathrm{b}}$ \\
Forte Plc & $0.427161^{\mathrm{a}}$ & $0.995671^{\mathrm{b}}$ & & $0.033517^{\mathrm{b}}$ & $0.928385^{\mathrm{b}}$ & $0.061117^{\mathrm{b}}$ \\
Mobil Plc & $0.410169^{\mathrm{a}}$ & $0.995835^{\mathrm{b}}$ & & $0.035217^{\mathrm{b}}$ & $0.926734^{\mathrm{b}}$ & $0.062053^{\mathrm{b}}$ \\
MRS Plc & $0.466006^{\mathrm{b}}$ & $0.995249^{\mathrm{b}}$ & & $0.048561^{\mathrm{b}}$ & $0.921975^{\mathrm{b}}$ & $0.063552^{\mathrm{b}}$ \\
Oando Plc & $0.146239^{\mathrm{b}}$ & $0.999039^{\mathrm{b}}$ & & $0.034501^{\mathrm{b}}$ & $0.256455^{\mathrm{b}}$ & $0.222403^{\mathrm{b}}$ \\
Total Plc & $0.398600^{\mathrm{a}}$ & $0.995949^{\mathrm{b}}$ & & 0.035005 & $0.061627^{\mathrm{b}}$ & $0.927270^{\mathrm{b}}$ \\
All Companies & $0.885887^{\mathrm{b}}$ & $0.990735^{\mathrm{b}}$ & & $0.007683^{\mathrm{b}}$ & $0.802001^{\mathrm{b}}$ & $0.300662^{\mathrm{b}}$ \\
\hline
\end{tabular}

${ }^{\mathrm{a}}$ and ${ }^{\mathrm{b}}$ indicate the significance at $5 \%$ and $10 \%$ confidence level respectively 


\section{Impulse response}

To examine how each stock price responds to innovations from oil price, we estimate the impulse response of the VAR system. Figure 1 presents the impulse response function result for stock price returns to an oil shock at the firm level (see also Appendix 3).

The results show that all company stock prices respond positively to shocks in the oil price in period 1, except FORTE and TOTAL PLC, which respond negatively to a standard deviation innovation in the oil price. On the other hand, all company stock prices respond negatively in period 20, except BECO and OANDO.

Specifically, periods 1 and 2 for BECO indicate that a shock to the oil price causes positive standard deviation values of 0.0018 and 0.0011 in stock returns. Figure 1 also shows a negative reaction of about 0.000028 standard deviations in stock returns due to a shock from oil in period 3, while stock return rises to a

Beco Petroleum Product Plc.

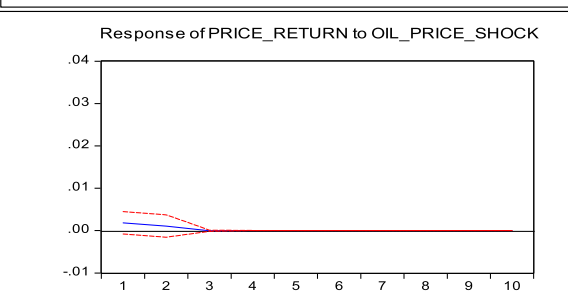

Eterna Plc.

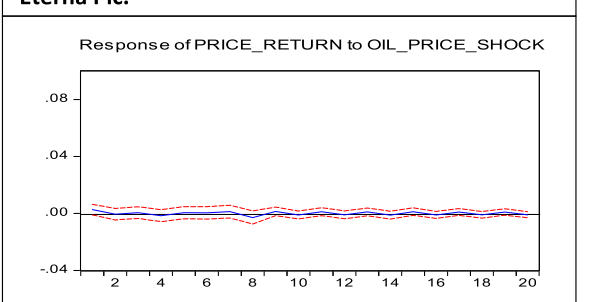

Mobil Oil Nigeria Plc
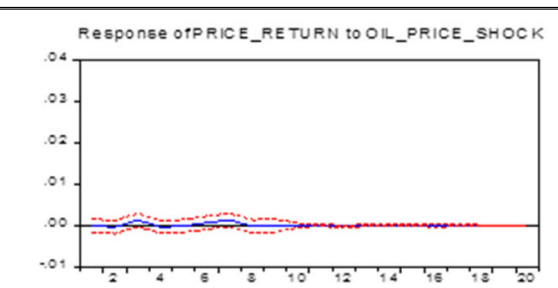

Oando Plc

Response of PRICE_RETURN to OIL_PRICE_SHOCK

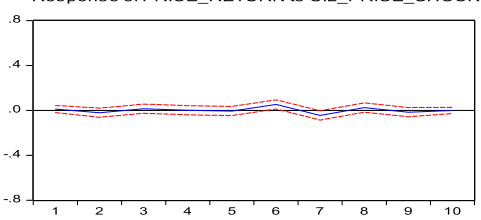

\section{Conoil PIc}

Response of PRICE_RETURN to OIL_PRICE_SHOCK

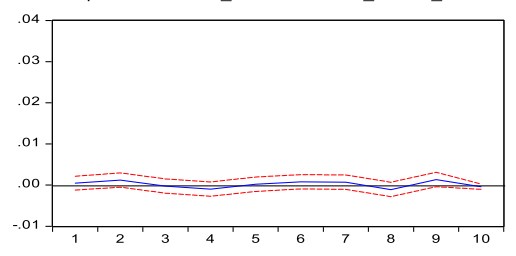

Forte Oil Plc

Response of PRICE_RETURN to OIL_PRICE_SHOCK

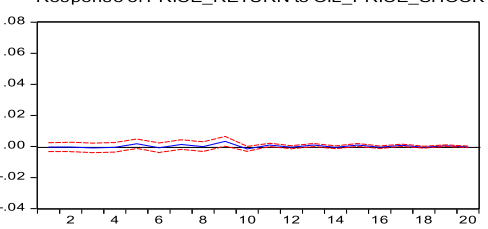

MRS Oil Nigeria Plc

Response OfPRICE_RETURN to OIL_PRICE_SHOCK

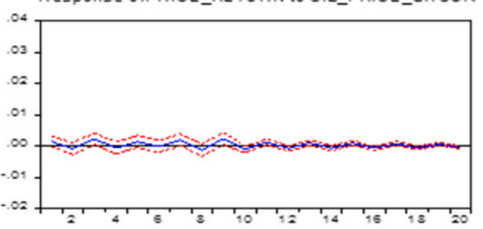

Total Nigeria Plc

Response of PRICE_RETURN to OIL_PRICE_SHOCK

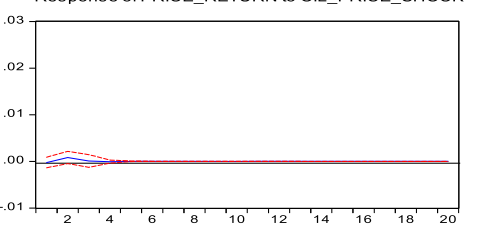

------=95\% confidence interval; —_- =predicted value; $x$ axis =periods; $y$ axis = percent

Fig. 1 Impulse response of stock price return to oil price shock per company 
positive value of 0.0000016 given a standard deviation shock from oil in period 4 . The reaction of the stock price returns to a shock from oil fluctuates through period 20.

CONOIL's stock return responds positively (0.00057) to a shock from oil in period 1. An increased standard deviation value of 0.0012 in period 2 indicates a positive response to an innovation from oil. This implies that CONOIL's stock return increases given a unit standard deviation shock in oil in period 2. Conversely, the standard deviation shock from oil reduces stock returns in periods 3 and 4, which show negative standard deviation values of 0.00026 and 0.00099 , respectively. It then remains positive through period 7 and afterwards fluctuates through to period 20.

ETERNA's stock return reacts positively to a shock from oil price in period 1, but negatively in period 2, with standard deviation values of 0.0027 and 0.00052 , respectively. In its reaction to oil in periods 3 and 4 , the stock price return rises and falls with standard deviation values of 0.00056 and 0.00158 . It then continues to move haphazardly through period 20. Additionally, the stock return also fluctuates through period 20 for FORTE, MOBIL, MRS, OANDO, and TOTAL after the initial positive responses (from MOBIL, MRS, and OANDO) and negative responses (from FORTE and TOTAL) in period 1, with standard deviation values 0 . 00046, 0.000066, 0.00145, 0.01108, and 0.00025, respectively.

\section{Variance decomposition}

We capture the relative contribution of oil price shocks to the variations in the stock return using variance decomposition. The results indicate the percentage of the forecast error of macroeconomic shocks at different time horizons from period 1 (short term) to period 20 (long term).

Generally, the results show that the variances of all company stock returns are mainly driven by oil price innovations starting from period 2 to 20, and the total fluctuations for each period increases for each firm except for BECO, with a constant value in periods 3 through 20 (see Appendix 4).

Considering BECO's 1st period, the results show that a shock from oil price causes no fluctuation in stock returns. A shock to the oil price will cause a $0.096 \%$ fluctuation in stock returns in period 2. An oil price shock in period 3 also accounts for about 99. $80 \%$ of the variation in the fluctuation of stock returns, and this continues through period 20. The result in period indicates that no fluctuation in the variation of CONOIL' stock return is due to innovations in the oil price. The $0.119 \%$ variation in the stock return is due to the shock from oil price in period 2. Additionally, a shock to oil price causes a $0.124 \%$ fluctuation in the variation of stock returns in period 3 . On the other hand, in period 20 (long term), a shock in the oil price causes a $0.477 \%$ fluctuation in stock returns.

The results also show that in the 2 nd period, oil price causes a $0.0044 \%$ variation in ETERNA stock returns and on the long run (period 20), causes a $0.0802 \%$ variation. Just like the other firms, the result shows that no fluctuation in the variation of FORTE, MOBIL, MRS, OANDO, and TOTAL's stock return is due to innovations in the oil price in period 1. A shock to the oil price will causes 0.0072, 0.0093, 0.0048, 0.0206, 
and $0.0742 \%$ fluctuations in FORTE, MOBIL, MRS, OANDO, and TOTAL's stock return in period 2, respectively. In the long run (period 20), a shock to the oil price causes 0.536, 0.388, 1.137, 0.773, and 0.075 fluctuations in FORTE, MOBIL, MRS, OANDO, and TOTAL's stock returns, respectively.

\section{Summary of results}

From the analysis above, we can deduce that stock returns for oil and gas companies in Nigeria fluctuate in their response to oil price shocks, from the first period until the 15th period, after which (periods 16 - 20) their stock returns begin to respond negatively to oil price shocks (see Appendix 5). The variance decomposition results show that in the 5th period, the oil price causes a $0.019414 \%$ variation in oil and gas stock returns. By the 20th period, the oil price caused up to a $0.110184 \%$ variation in oil and gas stock returns (see Appendix 6). Table 3 summarizes the core results.

Theoretically, oil price changes should affect stock markets (and hence company stock returns) in oil exporting countries positively. Empirical evidence also proves this positive relationship (Gjerde and Saettem 1999; Arouri and Fouquau 2009; Ono, 2011), specifically for the US (Al-Mudhaf and Goodwin 1993), Australia (Faff and Brailsford 1999), and the UK (Sadorsky 2001; Nandha and Faff 2008).

However, this study finds that in Nigeria, an oil exporting country, oil and gas company returns respond negatively to oil price shocks. These results are consistent prior studies that also find a negative response of Nigerian stocks to oil price shocks, despite the fact that Nigeria is an oil exporting nation (Babatunde et al. 2012; Asaolu and Ilo 2012; Effiong 2014).

Table 3 Response of stock to Brent oil price shocks per company

\begin{tabular}{|c|c|}
\hline Company & Response of stock to Brent oil price shocks \\
\hline Beco Petroleum Product Plc. & $\begin{array}{l}\text { Positive response to shocks in the first two periods, after which its } \\
\text { response fluctuates. In period 20, Beco stocks responded positively } \\
\text { to oil shocks }\end{array}$ \\
\hline Conoil Plc & $\begin{array}{l}\text { Positive response to shocks in the first two periods, after which its } \\
\text { response fluctuates. Between the 16th and the 20th period, Conoil } \\
\text { stocks responded more negatively to oil price shocks. }\end{array}$ \\
\hline Eterna Plc. & $\begin{array}{l}\text { Eterna stocks fluctuate from the } 1 \text { st to the 20th period. In period 20, } \\
\text { Eterna stocks respond negatively to oil price shocks. }\end{array}$ \\
\hline Forte Oil Plc & $\begin{array}{l}\text { Negative response to shocks in the first three periods, after which its } \\
\text { response fluctuates. Between the } 16 \text { th and the } 20 \text { th period, Conoil } \\
\text { stocks responded more negatively to oil price shocks. }\end{array}$ \\
\hline Mobil Oil Nigeria Plc. & $\begin{array}{l}\text { Fluctuating response from the } 1 \text { st period to the } 20 \text { th period. However, } \\
\text { between the } 16 \text { th and the } 20 \text { th period, Mobil stocks responded more } \\
\text { negatively to oil price shocks. }\end{array}$ \\
\hline MRS Oil Nigeria Plc & $\begin{array}{l}\text { Fluctuating response from the } 1 \text { st period to the } 20 \text { th period. However, } \\
\text { between the } 16 \text { th and the } 20 \text { th period, Mobil stocks responded more } \\
\text { negatively to oil price shocks. }\end{array}$ \\
\hline Oando Plc. & $\begin{array}{l}\text { Fluctuating response from the } 1 \text { st period to the 20th period. However, } \\
\text { between the } 16 \text { th and the 20th period, Mobil stocks responded more } \\
\text { negatively to oil price shocks. }\end{array}$ \\
\hline Total Nigeria Plc. & $\begin{array}{l}\text { Fluctuating response from the } 1 \text { st period to the 20th period. However, } \\
\text { between the } 16 \text { th and the 20th period, Mobil stocks responded more } \\
\text { negatively to oil price shocks. }\end{array}$ \\
\hline
\end{tabular}


In an analysis of the effects of oil price shocks on stock markets in Norway (an oil exporting country), Bjørnland (2009) argues that higher oil prices represent an immediate transfer of wealth from oil importers to exporters, stating that the medium to longterm effects depend on how the governments of oil producing countries dispose of the additional income. If used to purchase goods and services at home, higher oil prices will generate a higher level of activity, and thus improve stock returns.

Our results reveal that in Nigeria, when the oil price rises, oil and gas company stocks decline, a situation described in theory as peculiar to oil importing countries. We can trace this to the failure of the Nigerian government to transform huge foreign earnings from oil into an improved industrial sector within the economy. In addition, the failure to develop local refineries to transform crude produced within the country to refined petroleum products means that the country imports petroleum products, which could also be a good explanation for this as huge amounts of Nigeria's revenues are spent on a petroleum support fund and paying petroleum product marketers.

\section{Summary of findings}

In examining the trend of oil prices, the study revealed that oil prices throughout the period of study fluctuated continuously. In 2008, oil prices maintained an upward movement and rose to a new high of $\$ 145.01 /$ barrel by July. Easing tension between US and Iran caused crude prices to fall to $\$ 128 /$ barrel in August, and by the middle of September, the oil price fell below $\$ 100$ for the first time in over six months, to below $\$ 92$ in the aftermath of the US recession. By October 24, the price of crude dropped to $\$ 64.15$ and closed at $\$ 60.77$ on November 6. By the end of December 2008, oil bottomed out at $\$ 32$.

In 2009, the price of crude rose steadily from the $\$ 32$ low in December 2008. Following an OPEC cut of 4.2 million b/d in January 2009 prices rose steadily, which was supported by rising demand in Asia. By the end of the year, the crude oil price stood at \$74.42. In late February 2011, prices jumped due to the loss of Libyan exports in the face of the Libyan civil war. Concern about additional interruptions from unrest in other Middle East and North African producers continued to support the price, while as of mid-October, 400,000 barrels per day of Libyan production was restored.

Through much of 2012 and 2013, the impact of softening global demand on oil markets was offset by concerns about geopolitical risks and OPEC's pricing policies. Prices fluctuated within a narrow band around \$105/barrel until June 2014. By August 2014, Brent crude reached \$102.01, the lowest since June. By September, Brent Crude sold at \$97 and on October 16, West Texas crude fell below $\$ 80$ for the first time in more than two years, while Brent crude reached $\$ 82.60$, the lowest since November 2010. By December 2014, the price of oil was down $50 \%$ since April, as benchmark crude was at $\$ 54.11$ and Brent crude at $\$ 59$. 27, both the lowest since May 2009. This was largely due to economic problems in Europe and Asia, a strong dollar, higher US production, and no action by OPEC. In understanding the dynamics of oil and gas related stocks, the examination of the stock returns of the selected companies revealed that they largely moved in a pattern that reveals a relationship between the two variables. The preliminary statistics show that all daily stock returns exhibit excessive kurtosis, a fairly common occurrence in high frequency financial time series data.

In testing the effect of the oil price on oil and gas related stocks in Nigeria, the impulse response analysis shows that all companies' stock prices respond positively to 
shocks form the oil price in period 1, except FORTE and TOTAL PLC, which respond negatively to a standard deviation innovation from oil price. On the other hand, all companies' stock prices respond negatively in period 20, except BECO and OANDO. The variance decomposition reveals that the variances in all companies' stock returns are driven mainly by oil price innovations starting from period 2 to 20 , and the total fluctuations for each period increases for each firm except BECO, which maintained a constant value in periods 3 through 20 .

\section{Conclusion and recommendation}

This study investigated the impact of oil price shocks on eight oil-related stocks in Nigeria using a VAR model for the period between January 4, 2007 and December 31, 2014. The study adopts the scaled oil price increase method to transform oil prices into shock variables. Similarly, the oil stock prices were differenced once to obtain stock returns over the period. The empirical results suggest that oil price shocks significantly and rationally affect oil stocks in Nigeria. We conclude that oil price shocks have a proportionate impact on the stocks of Nigerian oil and gas companies.

This study's findings further buttress the fact that oil price uncertainty is a major concern to oil and gas company stock holders and management. We therefore recommend that Nigerian oil companies embrace the benefits of oil price hedging and energy risk management. Studies such as Jin and Jorison (2006) and Altuntas et al. (2017) highlight a major possible down side of hedging as having a negative relationship with firm value. Altuntas et al. (2017) did note its relevance in mitigating the negative effect of cash flow volatility. Hedging oil prices will therefore allow oil and gas companies to take a position in the crude oil futures market. Crude oil producing companies such as TOTAL or oil servicing firms such as CONOIL can enter crude oil futures contracts to purchase or sell crude oil at a particular future selling price. Hedging oil prices will allow the oil and gas industry more flexibility through better cash flow management.

However, this study's findings cannot serve as a basis for generalization because its scope is limited to oil stocks in Nigeria. We also note that emerging economies such as Nigeria may sometimes have low stock liquidity (Onoh 2016). Hence, the results of this study must be interpreted cautiously. Nevertheless, despite these caveats, our findings shed light on the relationship between oil prices and oil stocks. Future efforts could focus on testing the relationship between oil stocks and oil price shocks in other major oil exporting countries.

\section{Appendix 1}

Table $\mathbf{4}$ List of Companies and their Dates of Listing

\begin{tabular}{lll}
\hline S/N & Company & Date of NSE Listing \\
\hline 1. & Beco Petroleum Product Plc. & July, 2009 \\
2. & Conoil Plc & January, 1989 \\
3. & Eterna Plc. & August, 1998 \\
4. & Forte Oil Plc (Formerly African Petroleum) & January, 1978 \\
5. & Mobil Oil Nigeria Plc. & April, 1979 \\
6. & MRS Oil Nigeria Plc. (Formerly Chevron Oil Nigeria) & December 1978 \\
7. & Oando Plc. & February, 1992 \\
8. & Total Nigeria Plc. & April, 1979 \\
\hline
\end{tabular}




\section{Appendix 2}

Table $\mathbf{5}$ The lag length selection from VAR estimation

\begin{tabular}{lllllll}
\hline Lag & LogL & LR & FPE & AIC & SC & HQ \\
\hline 0 & $-16,253.62$ & NA & 0.035401 & 2.334740 & 2.335823 & 2.335100 \\
1 & $-14,453.04$ & 3600.402 & 0.027350 & 2.076702 & 2.079951 & 2.077784 \\
2 & $-13,967.98$ & 969.7718 & 0.025524 & 2.007609 & 2.013025 & 2.009412 \\
3 & $-13,473.82$ & 987.8226 & 0.023789 & 1.937209 & 1.944791 & 1.939734 \\
4 & $-13,318.16$ & 311.1171 & 0.023276 & 1.915427 & 1.925175 & 1.918673 \\
5 & $-13,158.84$ & 318.3813 & 0.022763 & 1.893119 & 1.905034 & 1.897087 \\
6 & $-13,007.63$ & 302.1346 & 0.022286 & 1.871976 & 1.886057 & 1.876665 \\
7 & $-12,777.58$ & 459.6069 & 0.021574 & 1.839509 & 1.855756 & 1.844919 \\
8 & $-12,718.27$ & $118.4676^{\mathrm{a}}$ & $0.021404^{\mathrm{a}}$ & $1.831566^{\mathrm{a}}$ & $1.849979^{\mathrm{a}}$ & $1.837697^{\mathrm{a}}$ \\
\hline
\end{tabular}

$L R$ sequential modified LR test statistic (each test at $5 \%$ level)

FPE Final prediction error

AIC Akaike information criterion

SC Schwarz information criterion

HQ Hannan-Quinn information criterion

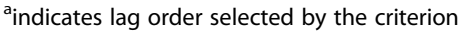

\section{Appendix 3}

Table 6 Impulse response of stock price return to oil price shock per company

\begin{tabular}{|c|c|c|c|c|c|c|c|c|}
\hline Period & Beco & Conoil & Eterna & Forte & Mobil & MRS & Oando & Total \\
\hline 1 & $\begin{array}{l}0.001833 \\
(0.00132)\end{array}$ & $\begin{array}{l}0.000468 \\
(0.00084)\end{array}$ & $\begin{array}{l}0.002703 \\
(0.00187)\end{array}$ & 80000 & $\begin{array}{l}6.60 \mathrm{E}-05 \\
(0.00076)\end{array}$ & $\begin{array}{l}0.001449 \\
(0.00086)\end{array}$ & $\begin{array}{l}0.011079 \\
(0.01567)\end{array}$ & $\begin{array}{l}-0.00025 \\
(0.00063)\end{array}$ \\
\hline 2 & 2) & 6) & $\begin{array}{l}-0.000522 \\
(0.00202)\end{array}$ & $\begin{array}{l}-0.00038 \\
(0.00151)\end{array}$ & $\begin{array}{l}-0.00034 \\
(0.00079)\end{array}$ & $\begin{array}{l}-0.00079 \\
(0.00091)\end{array}$ & $\begin{array}{l}-0.02191 \\
(0.02032)\end{array}$ & $\begin{array}{l}27 \\
5)\end{array}$ \\
\hline 3 & $\begin{array}{l}-2.83 \mathrm{E}-05 \\
(6.8 \mathrm{E}-05)\end{array}$ & $\begin{array}{l}-0.000257 \\
(0.00087)\end{array}$ & $\begin{array}{l}0.000557 \\
(0.00204)\end{array}$ & $\begin{array}{l}-0.00094 \\
(0.00152)\end{array}$ & & & & \\
\hline 4 & $158 \mathrm{E}-06$ & & & & & & & \\
\hline 5 & $\begin{array}{l}-6.50 \mathrm{E}-08 \\
(2.3 \mathrm{E}-07)\end{array}$ & $(0.00087)$ & & & & & & \\
\hline 6 & & חרח & 0.000 & 9 & $\begin{array}{l}\text { B6 } \\
\text { 9) }\end{array}$ & & & $\begin{array}{l}2.69 \mathrm{E}-06 \\
(1.1 \mathrm{E}-05)\end{array}$ \\
\hline 7 & & 000696 & & & & & & \\
\hline 8 & $586 \mathrm{~F}-12$ & & & & & & & \\
\hline 9 & & $(0.00088)$ & & & & & & \\
\hline 10 & $\begin{array}{l}1.16 \mathrm{E}- \\
(9.0 \mathrm{E}-\end{array}$ & $\begin{array}{l}-0.00 \\
(0.000\end{array}$ & $\begin{array}{l}-0.0 \\
(0.00\end{array}$ & $\begin{array}{l}-0.00 \\
(0.000\end{array}$ & $\begin{array}{l}0.000 \\
(0.00\end{array}$ & $\begin{array}{l}-0 \\
(0.0\end{array}$ & $\begin{array}{l}-0.00089 \\
(0.01401)\end{array}$ & $\begin{array}{l}-3.2 \\
(4.0 \mathrm{E}\end{array}$ \\
\hline 11 & $\begin{array}{l}-5.16 \mathrm{E}-16 \\
(4.4 \mathrm{E}-15)\end{array}$ & $\begin{array}{l}0.000317 \\
(0.00026)\end{array}$ & $\begin{array}{l}0.001190 \\
(0.00141)\end{array}$ & $\begin{array}{l}0.000920 \\
(0.00054)\end{array}$ & $\begin{array}{l}0.000133 \\
(0.00014)\end{array}$ & $\begin{array}{l}0.001279 \\
(0.00043)\end{array}$ & $\begin{array}{l}-0.00414 \\
(0.00419)\end{array}$ & $\begin{array}{l}-1.96 \mathrm{E}-09 \\
(2.1 \mathrm{E}-08)\end{array}$ \\
\hline 12 & $\begin{array}{l}2.29 \mathrm{E}-17 \\
(2.2 \mathrm{E}-16)\end{array}$ & $\begin{array}{l}-0.000211 \\
(0.00021)\end{array}$ & $\begin{array}{l}-0.000981 \\
(0.00138)\end{array}$ & $\begin{array}{l}-0.00054 \\
(0.00050)\end{array}$ & $\begin{array}{l}-0.00016 \\
(0.00013)\end{array}$ & $\begin{array}{l}-0.00074 \\
(0.000) 40\end{array}$ & $\begin{array}{l}0.005861 \\
(0.00414)\end{array}$ & $\begin{array}{l}3.00 \mathrm{E}-09 \\
(7.0 \mathrm{E}-09)\end{array}$ \\
\hline 13 & $\begin{array}{l}-1.02 \mathrm{E}-18 \\
(1.1 \mathrm{E}-17)\end{array}$ & $\begin{array}{l}0.000199 \\
(0.00020)\end{array}$ & $\begin{array}{l}0.001051 \\
(0.00139)\end{array}$ & 00052 & $\begin{array}{l}5.97 \mathrm{E} \\
(0.00\end{array}$ & $\begin{array}{l}0.00 \\
(0.00\end{array}$ & $\begin{array}{l}-0.00049 \\
(0.00402)\end{array}$ & $\begin{array}{l}-4.63 \mathrm{E}-10 \\
(8.4 \mathrm{E}-10)\end{array}$ \\
\hline 14 & $\begin{array}{l}4.54 \mathrm{E}-20 \\
(5.1 \mathrm{E}-19)\end{array}$ & $\begin{array}{l}-0.000217 \\
(0.00020)\end{array}$ & $\begin{array}{l}-0.001217 \\
(0.00137)\end{array}$ & $\begin{array}{l}-0.00062 \\
(0.00047)\end{array}$ & $\begin{array}{l}0.000205 \\
(0.00012)\end{array}$ & $\begin{array}{l}-0.00067 \\
(0.00037)\end{array}$ & $\begin{array}{l}0.007287 \\
(0.00378)\end{array}$ & $\begin{array}{l}-1.47 \mathrm{E}-10 \\
(6.5 \mathrm{E}-10)\end{array}$ \\
\hline 15 & $\begin{array}{l}-2.02 \mathrm{E}-21 \\
(2.4 \mathrm{E}-20)\end{array}$ & $\begin{array}{l}0.000284 \\
(2.4 \mathrm{E}-20)\end{array}$ & $\begin{array}{l}0.001251 \\
(0.00132)\end{array}$ & $\begin{array}{l}0.000861 \\
(0.00046)\end{array}$ & $\begin{array}{l}0.000118 \\
(0.00011)\end{array}$ & $\begin{array}{l}0.000927 \\
(0.00036)\end{array}$ & $\begin{array}{l}-0.00166 \\
(0.00355)\end{array}$ & $\begin{array}{l}6.87 \mathrm{E}-11 \\
(1.4 \mathrm{E}-10)\end{array}$ \\
\hline
\end{tabular}


Table 6 Impulse response of stock price return to oil price shock per company (Continued)

\begin{tabular}{lllllllll}
\hline Period & Beco & Conoil & Eterna & Forte & Mobil & MRS & Oando & Total \\
\hline 16 & $9.00 \mathrm{E}-23$ & -0.000261 & -0.001095 & -0.00054 & $-6.96 \mathrm{E}-05$ & -0.00069 & -0.00148 & $-2.56 \mathrm{E}-12$ \\
& $(1.2 \mathrm{E}-21)$ & $(0.00017)$ & $(0.00124)$ & $(0.00039)$ & $(0.00011)$ & $(0.00033)$ & $(0.00306)$ & $(3.2 \mathrm{E}-11)$ \\
17 & $-4.00 \mathrm{E}-24$ & 0.000208 & 0.001000 & 0.000671 & $2.91 \mathrm{E}-05$ & 0.000808 & -0.00076 & $-5.02 \mathrm{E}-12$ \\
& $(5.5 \mathrm{E}-23)$ & $(0.00014)$ & $(0.00119)$ & $(0.00037)$ & $(8.6 \mathrm{E}-05)$ & $(0.00032)$ & $(0.00285)$ & $(1.7 \mathrm{E}-11)$ \\
18 & $1.78 \mathrm{E}-25$ & -0.000138 & -0.000987 & -0.00052 & $3.68 \mathrm{E}-05$ & -0.00057 & -0.00191 & $1.26 \mathrm{E}-12$ \\
& $(2.6 \mathrm{E}-24)$ & $(0.00010)$ & $(0.00116)$ & $(0.00030)$ & $(5.7 \mathrm{E}-05)$ & $(0.00026)$ & $(0.00190)$ & $(2.4 \mathrm{E}-12)$ \\
19 & $-7.93 \mathrm{E}-27$ & 0.000116 & 0.000958 & 0.000457 & $-9.54 \mathrm{E}-06$ & 0.000587 & -0.00055 & $1.43 \mathrm{E}-13$ \\
& $(1.2 \mathrm{E}-25)$ & $(8.9 \mathrm{E}-05)$ & $(0.00113)$ & $(0.00026)$ & $(3.4 \mathrm{E}-05)$ & $(0.00024)$ & $(0.00172)$ & $(1.2 \mathrm{E}-12)$ \\
20 & $3.53 \mathrm{E}-28$ & $-9.89 \mathrm{E}-05$ & -0.00094 & -0.00033 & $-2.97 \mathrm{E}-05$ & -0.00044 & 0.000537 & $-1.32 \mathrm{E}-13$ \\
& $(5.8 \mathrm{E}-27)$ & $(7.9 \mathrm{E}-05)$ & $(0.00110)$ & $(0.00023)$ & $(2.7 \mathrm{E}-05)$ & $(0.00021)$ & $(0.00080)$ & $(4.1 \mathrm{E}-13)$ \\
\hline
\end{tabular}

\section{Appendix 4}

Table $\mathbf{7}$ Variance decomposition result per company

\begin{tabular}{|c|c|c|c|c|c|c|c|c|}
\hline Period & Beco & Conoil & Eterna & Forte & Mobil & MRS & Oando & Total \\
\hline 1 & $\begin{array}{l}0.000000 \\
(0.00000)\end{array}$ & $\begin{array}{l}0.000000 \\
(0.00000)\end{array}$ & $\begin{array}{l}0.000000 \\
(0.00000)\end{array}$ & $\begin{array}{l}0.000000 \\
(0.00000)\end{array}$ & $\begin{array}{l}0.000000 \\
(0.00000)\end{array}$ & $\begin{array}{l}0.000000 \\
(0.00000)\end{array}$ & $\begin{array}{l}0.000000 \\
(0.00000)\end{array}$ & $\begin{array}{l}0.000000 \\
(0.00000)\end{array}$ \\
\hline 2 & $\begin{array}{l}0.096307 \\
(0.33845)\end{array}$ & $\begin{array}{l}0.119111 \\
(0.18312)\end{array}$ & $\begin{array}{l}0.004400 \\
(0.06464)\end{array}$ & $\begin{array}{l}0.007168 \\
(0.06203)\end{array}$ & $\begin{array}{l}0.009262 \\
(0.07499)\end{array}$ & $\begin{array}{l}0.004801 \\
(0.05743)\end{array}$ & $\begin{array}{l}0.020618 \\
(0.06328)\end{array}$ & $\begin{array}{l}0.074292 \\
(0.12632)\end{array}$ \\
\hline 3 & $\begin{array}{l}0.096382 \\
(0.33940)\end{array}$ & $\begin{array}{l}0.123961 \\
(0.20274)\end{array}$ & $\begin{array}{l}0.004616 \\
(0.08057)\end{array}$ & $\begin{array}{l}0.024250 \\
(0.08474)\end{array}$ & $\begin{array}{l}0.164341 \\
(0.23457)\end{array}$ & $\begin{array}{l}0.267386 \\
(0.27852)\end{array}$ & $\begin{array}{l}0.046165 \\
(0.15460)\end{array}$ & $\begin{array}{l}0.074817 \\
(0.14941)\end{array}$ \\
\hline 4 & $\begin{array}{l}0.096382 \\
(0.33941)\end{array}$ & $\begin{array}{l}0.188018 \\
(0.24252)\end{array}$ & $\begin{array}{l}0.013356 \\
(0.13024)\end{array}$ & $\begin{array}{l}0.033524 \\
(0.10857)\end{array}$ & $\begin{array}{l}0.171099 \\
(0.26258)\end{array}$ & $\begin{array}{l}0.283804 \\
(0.32041)\end{array}$ & $\begin{array}{l}0.046455 \\
(0.17317)\end{array}$ & $\begin{array}{l}0.075257 \\
(0.15290)\end{array}$ \\
\hline 5 & $\begin{array}{l}0.096382 \\
(0.33941)\end{array}$ & $\begin{array}{l}0.188724 \\
(0.24495)\end{array}$ & $\begin{array}{l}0.012944 \\
(0.15011)\end{array}$ & $\begin{array}{l}0.104931 \\
(0.20691)\end{array}$ & $\begin{array}{l}0.172177 \\
(0.26767)\end{array}$ & $\begin{array}{l}0.351962 \\
(0.35482)\end{array}$ & $\begin{array}{l}0.053402 \\
(0.18272)\end{array}$ & $\begin{array}{l}0.075282 \\
(0.15300)\end{array}$ \\
\hline 6 & $\begin{array}{l}0.096382 \\
(0.33941)\end{array}$ & $\begin{array}{l}0.233855 \\
(0.25328)\end{array}$ & $\begin{array}{l}0.025982 \\
(0.18955)\end{array}$ & $\begin{array}{l}0.123565 \\
(0.26603)\end{array}$ & $\begin{array}{l}0.218189 \\
(0.28232)\end{array}$ & $\begin{array}{l}0.349757 \\
(0.35804)\end{array}$ & $\begin{array}{l}0.399444 \\
(0.34944)\end{array}$ & $\begin{array}{l}0.075282 \\
(0.15302)\end{array}$ \\
\hline 7 & $\begin{array}{l}0.096382 \\
(0.33941)\end{array}$ & $\begin{array}{l}0.263364 \\
(0.27621)\end{array}$ & $\begin{array}{l}0.028560 \\
(0.20071)\end{array}$ & $\begin{array}{l}0.157020 \\
(0.30507)\end{array}$ & $\begin{array}{l}0.384363 \\
(0.32798)\end{array}$ & $\begin{array}{l}0.521481 \\
(0.41480)\end{array}$ & $\begin{array}{l}0.658410 \\
(0.48326)\end{array}$ & $\begin{array}{l}0.075283 \\
(0.15302)\end{array}$ \\
\hline 8 & $\begin{array}{l}0.096382 \\
(0.33941)\end{array}$ & $\begin{array}{l}0.337932 \\
(0.32941)\end{array}$ & $\begin{array}{l}0.069673 \\
(0.21849)\end{array}$ & $\begin{array}{l}0.157260 \\
(0.32039)\end{array}$ & $\begin{array}{l}0.381687 \\
(0.33464)\end{array}$ & $\begin{array}{l}0.601869 \\
(0.47580)\end{array}$ & $\begin{array}{l}0.730104 \\
(0.51648)\end{array}$ & $\begin{array}{l}0.075283 \\
(0.15302)\end{array}$ \\
\hline 9 & $\begin{array}{l}0.096382 \\
(0.33941)\end{array}$ & $\begin{array}{l}0.443149 \\
(0.35713)\end{array}$ & $\begin{array}{l}0.071736 \\
(0.22976)\end{array}$ & $\begin{array}{l}0.393995 \\
(0.40738)\end{array}$ & $\begin{array}{l}0.379238 \\
(0.33618)\end{array}$ & $\begin{array}{l}0.844646 \\
(0.55663)\end{array}$ & $\begin{array}{l}0.764302 \\
(0.53368)\end{array}$ & $\begin{array}{l}0.075283 \\
(0.15302)\end{array}$ \\
\hline 10 & $\begin{array}{l}0.096382 \\
(0.33941)\end{array}$ & $\begin{array}{l}0.452539 \\
(0.36768)\end{array}$ & $\begin{array}{l}0.071897 \\
(0.24155)\end{array}$ & $\begin{array}{l}0.449334 \\
(0.44661)\end{array}$ & $\begin{array}{l}0.379357 \\
(0.33761)\end{array}$ & $\begin{array}{l}0.885989 \\
(0.58153)\end{array}$ & $\begin{array}{l}0.764401 \\
(0.53189)\end{array}$ & $\begin{array}{l}0.075283 \\
(0.15302)\end{array}$ \\
\hline 11 & $\begin{array}{l}0.096382 \\
(0.33941)\end{array}$ & $\begin{array}{l}0.457544 \\
(0.37410)\end{array}$ & $\begin{array}{l}0.072933 \\
(0.25610)\end{array}$ & $\begin{array}{l}0.466274 \\
(0.46453)\end{array}$ & $\begin{array}{l}0.380651 \\
(0.33955)\end{array}$ & $\begin{array}{l}0.948139 \\
(0.61405)\end{array}$ & $\begin{array}{l}0.761322 \\
(0.53018)\end{array}$ & $\begin{array}{l}0.075283 \\
(0.15302)\end{array}$ \\
\hline 12 & $\begin{array}{l}0.096382 \\
(0.33941)\end{array}$ & $\begin{array}{l}0.459661 \\
(0.37785)\end{array}$ & $\begin{array}{l}0.072336 \\
(0.26707)\end{array}$ & $\begin{array}{l}0.471985 \\
(0.47619)\end{array}$ & $\begin{array}{l}0.382678 \\
(0.34109)\end{array}$ & $\begin{array}{l}0.968696 \\
(0.63350)\end{array}$ & $\begin{array}{l}0.765642 \\
(0.53272)\end{array}$ & $\begin{array}{l}0.075283 \\
(0.15302)\end{array}$ \\
\hline 13 & $\begin{array}{l}0.096382 \\
(0.33941)\end{array}$ & $\begin{array}{l}0.461555 \\
(0.38101)\end{array}$ & $\begin{array}{l}0.072494 \\
(0.27890)\end{array}$ & $\begin{array}{l}0.486819 \\
(0.49215)\end{array}$ & $\begin{array}{l}0.382972 \\
(0.34140)\end{array}$ & $\begin{array}{l}1.009760 \\
(0.65915)\end{array}$ & $\begin{array}{l}0.765673 \\
(0.53356)\end{array}$ & $\begin{array}{l}0.075283 \\
(0.15302)\end{array}$ \\
\hline 14 & $\begin{array}{l}0.096382 \\
(0.33941)\end{array}$ & $\begin{array}{l}0.464063 \\
(0.38524)\end{array}$ & $\begin{array}{l}0.074395 \\
(0.29198)\end{array}$ & $\begin{array}{l}0.494459 \\
(0.50349)\end{array}$ & $\begin{array}{l}0.386392 \\
(0.34265)\end{array}$ & $\begin{array}{l}1.025894 \\
(0.67366)\end{array}$ & $\begin{array}{l}0.771974 \\
(0.53724)\end{array}$ & $\begin{array}{l}0.075283 \\
(0.15302)\end{array}$ \\
\hline 15 & $\begin{array}{l}0.096382 \\
(0.33941)\end{array}$ & $\begin{array}{l}0.468676 \\
(0.39018)\end{array}$ & $\begin{array}{l}0.076791 \\
(0.30372)\end{array}$ & $\begin{array}{l}0.509660 \\
(0.52022)\end{array}$ & $\begin{array}{l}0.387520 \\
(0.34400)\end{array}$ & $\begin{array}{l}1.059977 \\
(0.69391)\end{array}$ & $\begin{array}{l}0.772310 \\
(0.53782)\end{array}$ & $\begin{array}{l}0.075283 \\
(0.15302)\end{array}$ \\
\hline 16 & $\begin{array}{l}0.096382 \\
(0.33941)\end{array}$ & $\begin{array}{l}0.472500 \\
(0.39366)\end{array}$ & $\begin{array}{l}0.077846 \\
(0.31315)\end{array}$ & $\begin{array}{l}0.515385 \\
(0.53073)\end{array}$ & $\begin{array}{l}0.387740 \\
(0.34423)\end{array}$ & $\begin{array}{l}1.078689 \\
(0.70925)\end{array}$ & $\begin{array}{l}0.772566 \\
(0.53843)\end{array}$ & $\begin{array}{l}0.075283 \\
(0.15302)\end{array}$ \\
\hline 17 & $\begin{array}{l}0.096382 \\
(0.33941)\end{array}$ & $\begin{array}{l}0.474852 \\
(0.39603)\end{array}$ & $\begin{array}{l}0.078421 \\
(0.32169)\end{array}$ & $\begin{array}{l}0.524552 \\
(0.54136)\end{array}$ & $\begin{array}{l}0.387810 \\
(0.34443)\end{array}$ & $\begin{array}{l}1.104364 \\
(0.72583)\end{array}$ & $\begin{array}{l}0.772567 \\
(0.53864)\end{array}$ & $\begin{array}{l}0.075283 \\
(0.15302)\end{array}$ \\
\hline 18 & $\begin{array}{l}0.096382 \\
(0.33941)\end{array}$ & $\begin{array}{l}0.475836 \\
(0.39744)\end{array}$ & $\begin{array}{l}0.079049 \\
(0.32987)\end{array}$ & $\begin{array}{l}0.529953 \\
(0.54823)\end{array}$ & $\begin{array}{l}0.387909 \\
(0.34466)\end{array}$ & $\begin{array}{l}1.116201 \\
(0.73511)\end{array}$ & $\begin{array}{l}0.773023 \\
(0.53881)\end{array}$ & $\begin{array}{l}0.075283 \\
(0.15302)\end{array}$ \\
\hline 19 & $\begin{array}{l}0.096382 \\
(0.33941)\end{array}$ & $\begin{array}{l}0.476541 \\
(0.39858)\end{array}$ & $\begin{array}{l}0.079608 \\
(0.33737)\end{array}$ & $\begin{array}{l}0.534141 \\
(0.55356)\end{array}$ & $\begin{array}{l}0.387903 \\
(0.34470)\end{array}$ & $\begin{array}{l}1.129228 \\
(0.74370)\end{array}$ & $\begin{array}{l}0.772968 \\
(0.53880)\end{array}$ & $\begin{array}{l}0.075283 \\
(0.15302)\end{array}$ \\
\hline 20 & $\begin{array}{l}0.096382 \\
(0.33941)\end{array}$ & $\begin{array}{l}0.477056 \\
(0.39944)\end{array}$ & $\begin{array}{l}0.080209 \\
(0.34441)\end{array}$ & $\begin{array}{l}0.536259 \\
(0.55726)\end{array}$ & $\begin{array}{l}0.387976 \\
(0.34479)\end{array}$ & $\begin{array}{l}1.136536 \\
(0.74983)\end{array}$ & $\begin{array}{l}0.772950 \\
(0.53876)\end{array}$ & $\begin{array}{l}0.075283 \\
(0.15302)\end{array}$ \\
\hline
\end{tabular}




\section{Appendix 5}

Table $\mathbf{8}$ Impulse response of oil stock price return to oil price shock for all companies

\begin{tabular}{lll}
\hline Period & Price return $\left(\right.$ sprt $\left._{t}\right)$ & Oil shock (ost $)$ \\
\hline 1 & $0.264849(0.00130)$ & $0.000000(0.00000)$ \\
2 & $-0.209387(0.00238)$ & $0.001634(0.00260)$ \\
3 & $-0.002976(0.00265)$ & $-0.003339(0.00282)$ \\
4 & $-0.018838(0.00243)$ & $0.002875(0.00273)$ \\
5 & $0.018659(0.00273)$ & $-0.000433(0.00272)$ \\
6 & $-0.012607(0.00294)$ & $0.000665(0.00300)$ \\
7 & $0.007876(0.00280)$ & $0.008057(0.00297)$ \\
8 & $0.002949(0.00304)$ & $-0.005716(0.00306)$ \\
9 & $0.028356(0.00294)$ & $0.000861(0.00288)$ \\
10 & $-0.004433(0.00268)$ & $-0.002105(0.00206)$ \\
11 & $-0.015924(0.00137)$ & $0.000332(0.00046)$ \\
12 & $-0.004413(0.00074)$ & $-0.000478(0.00043)$ \\
13 & $0.001002(0.00075)$ & $0.000905(0.00047)$ \\
14 & $0.000125(0.00068)$ & $-0.000132(0.00038)$ \\
15 & $5.47 \mathrm{E}-05(0.00056)$ & $0.001063(0.00034)$ \\
16 & $0.001777(0.00059)$ & $-0.000184(0.00033)$ \\
17 & $0.003538(0.00061)$ & $-0.000314(0.00031)$ \\
18 & $0.001444(0.00054)$ & $-0.000294(0.00018)$ \\
19 & $-0.002263(0.00025)$ & $-8.21 \mathrm{E}-05(0.00016)$ \\
20 & $-0.001906(0.00026)$ & $-4.57 \mathrm{E}-05(6.4 \mathrm{E}-05)$ \\
\hline
\end{tabular}

\section{Appendix 6}

Table 9 Variance decomposition result for all companies

\begin{tabular}{llll}
\hline Period & aS.E. & Price return (sprt) & Oil shock (ost $)$ \\
\hline 1 & 0.264849 & $100.0000(0.00000)$ & $0.000000(0.00000)$ \\
2 & 0.337625 & $99.99766(0.01158)$ & $0.002343(0.01158)$ \\
3 & 0.337654 & $99.98788(0.02457)$ & $0.012122(0.02457)$ \\
4 & 0.338192 & $99.98069(0.03443)$ & $0.019309(0.03443)$ \\
5 & 0.338706 & $99.98059(0.03660)$ & $0.019414(0.03660)$ \\
6 & 0.338941 & $99.98023(0.03751)$ & $0.019772(0.03751)$ \\
7 & 0.339129 & $99.92380(0.05212)$ & $0.076199(0.05212)$ \\
8 & 0.339190 & $99.89543(0.07036)$ & $0.104570(0.07036)$ \\
9 & 0.340374 & $99.89552(0.07420)$ & $0.104483(0.07420)$ \\
10 & 0.340409 & $99.89171(0.07645)$ & $0.108286(0.07645)$ \\
11 & 0.340782 & $99.89186(0.07647)$ & $0.108145(0.07647)$ \\
12 & 0.340811 & $99.89168(0.07681)$ & $0.108323(0.07681)$ \\
13 & 0.340813 & $99.89097(0.07716)$ & $0.109027(0.07716)$ \\
14 & 0.340813 & $99.89096(0.07726)$ & $0.109042(0.07726)$ \\
15 & 0.340815 & $99.88999(0.07778)$ & $0.110013(0.07778)$ \\
16 & 0.340820 & $99.88996(0.07784)$ & $0.110039(0.07784)$ \\
17 & 0.340838 & $99.88989(0.07785)$ & $0.110112(0.07785)$ \\
18 & 0.340841 & $99.88982(0.07785)$ & $0.110184(0.07785)$ \\
19 & 0.340849 & $99.88981(0.07785)$ & $0.110185(0.07785)$ \\
20 & 0.340854 & $99.88982(0.07785)$ & $0.110184(0.07785)$ \\
\hline$S . E . S t a n s)$ & &
\end{tabular}


Funding

We would like to disclose that no funding was received in the process of this study.

\section{Authors' contributions}

We would like to disclose that this article was borne out of a dissertation by AU-P with the assistance of TL under the supervision of AA. AU-P provided the literature review and jointly conducted the analysis and discussion with TL. TL provided the analytical framework and jointly conducted the analysis and discussion with AU-P. AA provided the Conceptual framework for the study and supervised the study. All authors read and approved the final manuscript.

\section{Competing interests}

The authors declare that they have no competing interests.

\section{Received: 8 July 2017 Accepted: 15 March 2018}

Published online: 11 April 2018

\section{References}

Adaramola AO (2012) Oil price shocks and stock market behaviour: the Nigerian experience. J Econ 3(1):19-24

Al-Mudhaf A, Goodwin TH (1993) Oil shocks and oil stocks: evidence from the 1970s. Appl Econo 25(2):181-190

Altuntas M, Liebenberg AP, Watson ED, Yildiz S (2017) Hedging, cash flows, and firm value: evidence of an indirect effect. J Insur Issues 40(1):1-22

Arouri ME, Fouquau J (2009) On the short-term influence of oil price changes on stock markets in GCC countries: linear and nonlinear analyses. Econ Bull 29(2):795-804

Asaolu TO, Ilo BM. (2012). The Nigerian stock market and oil price: A cointegration analysis. Kuwait Chapter of Arabian J. of Bus and Management Review. 1(5), pp. 39-54

Aziz MIA, Dahalan J (2015) Oil price shocks and macroeconomic activities in Asean-5 countries: a panel VAR approach. Eurasian J of Bus and Econ 8(16):101-120

Babatunde M, Adenikinju A, Adenikiju O (2012) Oil price shocks and stock market behavior in Nigeria. J Econ Stud 40(2):180-202

Babatunde M, Adenikinju O, Adenikinju AF (2013) Oil price shocks and stock market behaviour in Nigeria. J Econ Stud 40(2):180-202

Basher S, Sadorsky P (2006) Oil Price Risk and Emerging Stock Markets. Glob Financ J 17(2):224-251

Bjørnland H (2009) Oil price shocks and stock market booms in an oil exporting country. Scott J Polit Econ 56(2):232-254

Bollerslev T (1986) Generalized autoregressive conditional heteroskedasticity. J Econ 31(3):307-327

Chen NF, Roll R, Ross SA (1986) Economic forces and the stock market. J Bus 59(3):383-403

Effiong E (2014) Oil price shocks and Nigeria's stock market: what have we learned from crude oil market shocks? OPEC Energy Rev 38(1):36-58

Faff RW, Brailsford TJ (1999) Oil price risk and the Australian stock market. J Energy Financ Dev 4(1):69-87

Gjerde $\varnothing$, Saettem $F$ (1999) Causal relations among stock returns and macroeconomic variables in a small, open economy. J Int Financ Mark Inst Money 9(1):61-74

Hamao Y (1988) An empirical examination of the arbitrage pricing theory: using Japanese data. Jpn World Econ 1(1):45-61

Huang RD, Masulis RW, Stoll HR (1996) Energy shocks and financial markets. J Futur Mark 16(1):1-27

Jiménez-Rodríguez R, Sánchez M (2005) Oil price shocks and real GDP growth: empirical evidence for some OECD countries. Appl Econ 37(2):201-228

Jin Y, Jorison P (2006) Firm value and hedging: Evidence from US oil and gas producers. J Financ 61 (2):893-919 Jones C, Kaul G (1996) Oil and the stock markets. J Financ 51(2):463-491

Lee K, Ni S, Ratti RA (1995) Oil shocks and the macroeconomy: the role of price variability. Energy J 16(4):39-56

Nandha M, Faff R (2008) Does oil move equity prices? A global view. Energy Econ 30(3):986-997

Ono S (2011) Oil price shocks and stock markets in BRICs. Eur J Comp Econ 8(1):29-45

Onoh JO (2016) The effect of stock market liquidity on daily returns in the Nigerian capital market. Intl J Bank Financ Res 2(1):54-72

Parivash GH, Tarkamani J (2008) Effects of financial markets development on growth of agricultural sector. Am Eurasian J Agric Environ Sci 2(1):166-178

Roll R, Ross SA (1984) The arbitrage pricing theory approach to strategic portfolio planning. Financ Anal J 40(3):14-26

Ross SA (1976) The arbitrage theory of capital asset pricing. J Econ Theory 13(3):341-360

Sadorsky P (1999) Oil price shocks and stock market activity. Energy Econ 21(5):449-469

Sadorsky P (2001) Risk factors in stock returns of Canadian oil and gas companies. Energy Econ 23(1):17-28 